\title{
Demography of Jammu and Kashmir in Historical Perspective
}

\author{
Bilal Ahmad Khan \\ Jawaharlal Nehru University, New Delhi, India \\ E-Mail: drbilalpdfjnu786@gmail.com/bilalahmadk9@gmail.com
}

\begin{abstract}
At the time of the birth of India and Pakistan, the state of J\&K with a population of four million people, most of it concentrated in the fertile valley of the Jhelum River of the Indus River system, was one of the least developed regions in the Indian sub-continent. The economy of the state was overwhelmingly rural and agricultural in character. Nearly 90 percent of people lived in villages and derived their livelihood from agricultural and related pursuits using traditional and low productivity techniques. The extreme backwardness of the state was reflected by the abysmal mass poverty, low literacy, high birth and death rate, low life expectancy, low population density etc. The size of population and its growth have a direct bearing on the economic development, social well being and political stability of a region. The history of population growth in the Jammu and Kashmir State is a record of constant impulses of immigration from the north-west, west-south and east directions. The main objective of the paper is to look the nature and trends of population change since the birth of Jammu and Kashmir and also examine thedemographic trends in view of historical perspectives of Jammu \& Kashmir State. The State has great diversity in its terrain, climatic conditions and resource base which resulted uneven distribution of population.
\end{abstract}

Keywords: Poverty, Birth and Death Rate, Life Expectancy, Population Density, Immigration and Uneven distribution

\section{INTRODUCTION}

Geologists of the region are of the view that Kashmir emerged more than a hundred million years ago. There are various versions of historical backgrounds available for the State of Jammu \& Kashmir in general and for the valley of Kashmir in particular. According to Rajtarangani, the Kashmir Valley was once a large lake 'Satisar' (Durga), home to ferocious demons.

According to folk etymology, the name "Kashmir" means "desiccated land" (In Sanskrit: Ka means water and shimeera means desiccate). The lake was drained by the great rishi Kashyapa, son of Brahma, by cutting the gap in the hills at Baramulla (Varaha-mula). When the lake had been drained, Kashyapa asked Brahmans to settle there. Geologists said that geographical gradual changes made way for the outflow of water by subsidence of the mountain at Khadianayar, Baramulla.Thus the Kashmir Valley had been emerged (Kalhan, 1148 A.D) ${ }^{l}$.

The State of Jammu and Kashmir is one of the largest States of the Indian Union and is situated in the lap of the mighty Himalayas. It lies between $32 \mathrm{o}-15^{\prime}$ to $37 \mathrm{o}-05^{\prime}$ latitude north and $720-35^{\prime}$ to $800-20$ ' longitudes east. The state has a geographical area of 222, 236 sq.kms. comprising 6.93 per cent of the total Indian Territory which includes 78,114 sq. kms. under illegal occupation of Pakistan and 5,180 sq.kms. illegally handed over by Pakistan to China and 37,555 sq.kms. under illegal occupation of China in Leh (Ladakh) district. This leaves the state with an area of 101,387 sq. $\mathrm{kms}$ which is demarcated into 22 districts.

The Jammu \& Kashmir State has a unique geographical entity. It is well bestowed with natural resources, mighty rivers, evergreen forests, snow-covered peaks and humane population that are famous throughout the world. This northern most state of India is bounded in the north-east by China, in the north-west by Afghanistan, and in the west by Pakistan. The southern boundary is contiguous with the states of Punjab and Himachal Pradesh (Rahman, 1996) ${ }^{7}$. The State possesses a variety of climate. For instance, Jammu has tropical climate, while Kashmir situated in the sub-tropical area is subject to an extraordinary variations of temperature. (JKEco.Survey, 2013-14) ${ }^{36}$.

\section{OBJECTIVES}

1. To look the nature and trends of population change since the birth of Jammu and Kashmir

2. To examine thedemographic trends in view of historical perspectives of J\&K State.

\section{DISCUSSION AND FINDINGS}

The State has no physical monotony but presents an interesting morphology. The immense diversity of State can be broadly grouped into three main regions, namely Jammu, Kashmir and Ladakh, recognized by its constitution. Geographically, the PirPanchal range separates Jammu from Kashmir Valley, while the Zojila intervenes between the latter and Ladakh.

\section{A. Nature of Population Growth in Jammu \& Kashmir State}

At the time of the partition of British India, the state had a population of slightly more than four million, one million of whom were in the areas that were occupied by Pakistan during the first Kashmir war of 1948-49. The remaining three million lived in the part of the state that was to be controlled by India. The population in the Indian part of Kashmir increased at a rate of less than 1 percent annually till 1971. After that, the growth rate increased threefold to 2.6 percent a year. It stayed at that level for three decades. 
The sudden jumps in some periods reflect some migration into the area from other parts of India $\left(\right.$ Burki, 2007) ${ }^{8}$.

The history of population growth in the J\&K State is a record of constant impulses of immigration from the northwest, west-south and east directions. The alien races, ethnic groups and various religions have influenced the cultural ethos and mode of life of this region. The State has great diversity in its terrain, climatic conditions and resource base which resulted uneven distribution of population. The heavy increase of population in the State from past seven decades is reflects in table $\mathrm{I}$.

\begin{tabular}{|c|c|c|c|c|c|c|c|c|c|}
\hline Year & T. Pop & Male & \% & Fem & \% & Rural & \% & Urban & $\%$ \\
\hline 1941 & 29.46 & 15.77 & 53.51 & 13.69 & 46.49 & 25.60 & 86.88 & 3.86 & 13.12 \\
\hline 1951 & 32.53 & 17.16 & 53.36 & 15.17 & 46.64 & 27.96 & 85.95 & 4.57 & 14.05 \\
\hline 1961 & 35.60 & 18.96 & 53.25 & 16.64 & 46.75 & 29.67 & 83.34 & 5.93 & 16.66 \\
\hline 1971 & 46.16 & 24.58 & 53.25 & 21.58 & 46.76 & 37.58 & 81.41 & 8.58 & 18.59 \\
\hline 1981 & 59.87 & 31.64 & 52.84 & 28.22 & 47.16 & 47.26 & 78.95 & 12.60 & 21.05 \\
\hline 1991 & 77.18 & 40.14 & 52.00 & 37.04 & 48.00 & 58.79 & 76.17 & 18.39 & 23.83 \\
\hline 2001 & 100.69 & 53.00 & 52.63 & 47.36 & 47.36 & 75.64 & 75.12 & 25.05 & 24.88 \\
\hline 2011 & 125.48 & 66.65 & 53.11 & 58.83 & 46.88 & 91.34 & 72.79 & 34.14 & 27.20 \\
\hline
\end{tabular}

Note: (i) 1951 figures of population are the arithmetical mean of 1941 \& 1961 populations, as in 1951, Census was not held in J\&K State.

(ii) - The 1991 Census was not held in Jammu and Kashmir. The population figures are as projected by the Standing Committee o f Experts on Population Projections (October 1989)

Prior to 1921, the population of the State grew at a slow rate because the State experienced number of famines and epidemics ((Census of India, 1921) ${ }^{9}$. After 1921, however, the population increased steadily. In 1941, the population of the Stale was 29.46 lakhs, out of which 15.77 lakhs $(53.51$ per cent) were males and 13.69 (46.49 per cent) females. In 1951 , soon after the partition, the population of the State reached to 32.53 lakhs. During 1961-71, the population of the State proliferated from 35.60 lakhs to 46.16 lakhs, thus showing an increase of 10.56 lakhs. As per 1981 Census, the total population of the State was 59.87 lakhs with 52.84 per cent males and 47.16 per cent females (Census of India, $1941)^{10}$.

The figures of 2001 Census showed that the population of the Stale crossed one crore mark showing a total population of 100.69 lakhs with 53.00 lakhs males (52.63\%) and 47.36 lakhs females $(47.36 \%)$. Again census 2011 showed that the population of the Stale increased 125.48 lakhs with 66.65 lakhs males (53.11\%) and 58.83 lakhs females (46.88\%). Thus it becomes articulate fixing the data that population in the State has increased by 96.02 lakhs from 1941-2011. Agriculture is the main stay of economy, thus majority of population live in the rural areas. The rural population in the State is three times more than the urban population as shown in Table 1.1. According to the Census report of $1941,86.88$ per cent of the total population of the State was residing in the villages and the remaining 13.12 per cent in urban areas. During 1961-71, the percentage of urban population increased from 16.66 per cent to 18.59 per cent and the trend continued as shown in the table 3.1. According to 1991 estimates, the rural population was 76.17 per cent while as that of urban population was 23.83 percent. The Census of 2011 showed 72.79 percent of rural population while as 27.20 percent urban population (Census of India, 2011) ${ }^{15}$.

The Kashmir province accounts higher proportion of rural population than in Jammu province. However, percentage of total population living in villages has declined decade after decade. In fact, people from rural areas have migrated to urban areas because of security reasons, education, medical facilities and employment opportunities.

\section{B. Population Growth in Jammu \& Kashmir State, 1901 - 2011}

Yet an analysis of the development process over the past decades shows that one of the major causes for slow economic and social development has been unplanned population growth. Its optimum size, growth, composition and quality of population play an important role in the development process. There is, however, no clear-cut yardstick to calculate the optimum size and rate of growth of population. A large population undergoing hyper growth in a poor economy with limited resources and rudimentary technology can be a liability. Contrary to this, when a population is productively employed, it can be an asset and a resource. Thus stabilization of population is the most important factor (Annual Report, Health \& Family Welfare, $1998)^{32}$.

The state has witnessed a fluctuating population growth rate since 1901. Population trend is examined since the beginning of this century using the census data. The beginning of the century witnessed breakouts of cholera, pneumonia followed by floods and earthquakes which took a heavy toll of life in Kashmir Division. In Jammu division also, plague, enteric fever and famine remained active 
throughout this period. In the first two decades of the 20th century the population growth was below 10 per cent. After 1931 , it rose at a constant rate of 10 per cent per decade up to 1961 , thereafter; an unprecedented rise of 29 per cent per decade was highest growth rates among the all states in the country.

During the decade 1921-31, there was a severe famine in the Jammu division followed by cholera, small pox and plague in the state. The census year 1931 marks a watershed in the demographic history of the state with a discernible change between the decades since 1931 (Census, 1941) ${ }^{10}$. This can be attributed to the fact that the general population itself has grown rapidly through natural increase; this growth has occurred in all regions and affected almost all population groups in the towns and villages. The accentuated growth rate is recorded only after 1960s. Data shows sudden spurt in population from 9.44 per cent in 1961 to 29.65 percent in 1971, then 29.69 percent in 1981, 28.92, 30.46 and 23.71 percent in 1991, 2001 and 2011. The population growth of J\&K from 1901 to 2011 is reflected in table below.

TABLE II POPULATION GROWTH IN JAMMU AND KASHMIR, 1901-2011

\begin{tabular}{|c|c|c|c|c|c|}
\hline \multirow{2}{*}{ Year } & \multirow{2}{*}{$\begin{array}{c}\text { Population } \\
\text { (in Lakhs) }\end{array}$} & Absolute Change (Lakhs) & \multicolumn{2}{|c|}{ Decadal Variation } & \multirow{2}{*}{$\begin{array}{c}\text { Average Annual } \\
\text { Growth Rate }\end{array}$} \\
\cline { 4 - 5 } & & J \&K & India & - \\
\hline 1901 & 21.39 & ---- & - & - & 0.69 \\
\hline 1911 & 22.92 & 1.53 & 7.16 & 5.75 & 0.56 \\
\hline 1931 & 24.24 & 1.31 & 5.75 & -0.31 & 0.97 \\
\hline 1941 & 26.70 & 2.45 & 10.14 & 11.0 & 0.99 \\
\hline 1951 & 32.53 & 2.76 & 10.36 & 14.22 & 1.00 \\
\hline 1961 & 35.60 & 3.07 & 10.42 & 13.31 & 0.91 \\
\hline 1971 & 46.16 & 3.07 & 9.44 & 21.64 & 2.63 \\
\hline 1981 & 59.87 & 10.55 & 29.65 & 24.80 & 2.63 \\
\hline $1991 *$ & 77.18 & 13.70 & 29.69 & 24.66 & 2.57 \\
\hline 2001 & 100.69 & 17.31 & 28.92 & 23.86 & 2.69 \\
\hline 2011 & 125.48 & 23.51 & 30.46 & 21.34 & 2.63 \\
\hline
\end{tabular}

Source: Various issues, Census of India, Jammu and Kashmir

*The 1991 census was not held in J\&K. The population of India includes projected population of J\&K (excludes area under occupation of Pakistan and China) as on 1.3.1991 made by the Standing Committee of Experts.

However, since 1971, there was great change in absolute terms. In 1971 census, J\&K stands 46.16 lakhs, and then proliferated to $59.87,77.18,100.69$ and 125.48 lakhs in 1981, 1991, and 2001 and in 2011, reflects more than 25 percent decadal variation since 1971 against nation experienced below than 25 percent in the same periods. The annual growth rate is more than two percent since 1971. The annual growth rate of 2.63, 2.63, 2.57, 2.69 and 2.63 percent is reflected during the same period of 1971, 1981, 1991, 2001 and 2011 respectively. According to the 2001 census, the size of J\&K's population is 100.69 lakhs i.e., 0.98 per cent at all India level and 1.01 per cent (125.48 lakhs) according to the 2011 census.

\section{District Wise Population Growth Rate for J\&K (1951- 2001)}

The distribution of population since 1951 shows almost the same trend. In 1951, seven districts had 5-10 per cent of the state population. Due to the decline in the share of population in Rajauri district, in 1961 and 1971, six districts remained in the category of having 5-10 per cent of the growth rate of state's population. In Leh and Kargil district, a little more than 1 per cent of the population is found. This is because of undulating topography and harsh climate has restrained people from settling there (Census, 1971) $)^{12}$.

TABLE III DISTRICT-WISE GROWTH RATE OF POPULATION FOR J\&K, 19512001, PERCENT

\begin{tabular}{|l|l|l|l|l|l|}
\hline District & $\mathbf{1 9 5 1}$ & $\mathbf{1 9 6 1}$ & $\mathbf{1 9 7 1}$ & $\mathbf{1 9 8 1}$ & $\mathbf{2 0 0 1}$ \\
\hline Kupwara & 5.75 & 5.73 & 5.58 & 5.49 & 6.36 \\
\hline Baramulla & 11.05 & 11.01 & 11.10 & 11.19 & 11.59 \\
\hline Srinagar & 12.01 & 12.36 & 12.22 & 11.83 & 12.30 \\
\hline Badgam & 5.84 & 6.01 & 5.83 & 6.13 & 5.90 \\
\hline Pulwama & 6.87 & 6.95 & 6.80 & 6.75 & 6.28 \\
\hline Anantnag & 11.13 & 11.27 & 11.22 & 10.96 & 11.62 \\
\hline Leh & 1.24 & 1.22 & 1.12 & 1.14 & 1.17 \\
\hline Kargil & 1.29 & 1.27 & 1.16 & 1.10 & 1.14 \\
\hline Doda & 7.06 & 7.37 & 7.41 & 7.10 & 6.86 \\
\hline Udhampur & 7.32 & 7.31 & 7.42 & 7.58 & 7.34 \\
\hline Punch & 4.53 & 4.34 & 3.70 & 3.74 & 3.69 \\
\hline Rajauri & 5.46 & 4.82 & 4.71 & 5.05 & 4.75 \\
\hline Jammu & 14.43 & 14.41 & 15.70 & 15.76 & 15.61 \\
\hline Kathua & 6.01 & 5.92 & 6.02 & 6.17 & 5.40 \\
\hline J\&K & 100.0 & 100.0 & 100.0 & 100.0 & 100.0 \\
\hline
\end{tabular}

Source: Calculated from the census data of 1971, 1981 and $2001 \& 2001$ 
Thus is also a great deal of variation in the rate of growth of population in terms of spatial dimension. Major districts experienced an average annual growth rate ranging around 1 percent and some around 14 percent during the reference period from 1951 to 2001. Most of these districts form a pocket surrounding Srinagar district. It is very important to note that the districts having influence of the urban agglomerations have a better average annual growth compared to other districts. Four districts Srinagar, Anantnag, Baramulla and Jammu experienced average annual growth rate ranging 10 percent to 15 percent from 1951 to 2001. The district-wise growth rate of population since 1951 (up to 2001) in the J\&K State is depicted in the table below.

The Jammu district ranks the top among all the districts in the average growth rate of population. From 1971 to 2001, Jammu district accounts more than 15 percent of average growth rate of population. During the period between 1951 and 2001, Leh and Kargil district found only 1-2 per cent of the average growth rate of population due to harsh climate that has restrained people from settling there. In other districts, it can be assumed that male members have migrated to cities where employment opportunities are better compared to the villages.

\section{District-Wise Population for Jammu \& Kashmir, 2011}

According to census 2011, total population of the state stands 125.48 lakhs and district Jammu accounts highest proportion (15.26 lakhs) followed by Srinagar (12.69 lakhs) due to urbanization which causes rapid migration from rural areas. Decadal growth rate during 2001-11 records 23.71 percent. According to census 2011, sex ratio stands at 883 per thousand males. The District-wise population of Jammu \& Kashmir State, as per Census 2011 is depicted in the table below.

TABLE IV DistRICT-WISE POPULATION OF J \& K STATE, CENSUS 2011

\begin{tabular}{|c|c|c|c|c|c|c|c|c|}
\hline \multirow{2}{*}{ District } & \multicolumn{3}{|c|}{ Total Pop (Lakhs) } & \multirow{2}{*}{$\begin{array}{c}\text { Decadal Growth } \\
\text { Rate (2001-11) }\end{array}$} & \multirow{2}{*}{$\begin{array}{l}\text { Sex } \\
\text { ratio }\end{array}$} & \multirow{2}{*}{$\begin{array}{l}\text { Pop Density } \\
\text { Per Sq. Km }\end{array}$} & \multicolumn{2}{|c|}{$\begin{array}{l}\text { Proportion of District } \\
\text { Pop to State Total Pop }\end{array}$} \\
\hline & M & $\mathbf{F}$ & $\mathbf{T}$ & & & & M & $\mathbf{F}$ \\
\hline Kupwara & 4.75 & 40.04 & 8.75 & 34.62 & 843 & 368 & 3.79 & 3.19 \\
\hline Baramula & 5.42 & 4.73 & 10.1 & 20.34 & 873 & 305 & 4.32 & 3.77 \\
\hline Srinagar & 6.75 & 5.94 & 12.6 & 23.56 & 879 & 703 & 5.38 & 4.73 \\
\hline Badgam & 3.90 & 3.55 & 7.35 & 21.18 & 883 & 537 & 3.11 & 2.75 \\
\hline Pulwama & 2.97 & 2.72 & 5.70 & 29.18 & 913 & 598 & 2.37 & 2.17 \\
\hline Anantnag & 5.52 & 5.17 & 10.7 & 37.48 & 937 & 375 & 4.40 & 4.13 \\
\hline Leh & 0.92 & 0.54 & 1.47 & 25.48 & 583 & 3 & 0.74 & 0.43 \\
\hline Kargil & 0.80 & 0.62 & 1.43 & 20.18 & 775 & 10 & 0.64 & 0.50 \\
\hline Doda & 2.13 & 1.96 & 0.40 & 27.89 & 922 & 79 & 1.70 & 1.57 \\
\hline Udampur & 2.98 & 2.57 & 5.55 & 20.86 & 863 & 211 & 2.38 & 2.05 \\
\hline Punch & 2.52 & 2.24 & 4.76 & 27.97 & 890 & 285 & 2.01 & 1.79 \\
\hline Rajauri & 3.32 & 2.86 & 6.19 & 28.14 & 863 & 235 & 2.65 & 2.29 \\
\hline Jammu & 8.15 & 7.10 & 15.2 & 12.48 & 871 & 596 & 6.50 & 5.66 \\
\hline Kathua & 3.27 & 2.87 & 6.15 & 20.38 & 877 & 232 & 2.61 & 2.29 \\
\hline Samba & 1.68 & 1.49 & 3.18 & 16.90 & 886 & 318 & 1.35 & 1.19 \\
\hline Reasi & 1.66 & 1.48 & 3.14 & 27.06 & 891 & 184 & 1.33 & 1.18 \\
\hline Kishtwar & 1.20 & 1.10 & 2.31 & 21.06 & 917 & 125 & 0.96 & 0.88 \\
\hline Ganderbal & 1.58 & 1.38 & 2.97 & 36.30 & 869 & 1151 & 1.27 & 1.10 \\
\hline Kulgam & 2.16 & 2.06 & 4.22 & 7.30 & 951 & 925 & 1.73 & 1.64 \\
\hline Ramban & 1.49 & 1.34 & 2.83 & 31.81 & 901 & 213 & 1.19 & 1.07 \\
\hline Shopian & 1.36 & 1.29 & 2.65 & 25.85 & 951 & 852 & 1.09 & 1.03 \\
\hline Bandipore & 2.01 & 1.83 & 3.85 & 26.31 & 911 & 1117 & 1.61 & 1.46 \\
\hline $\mathrm{J} \& \mathrm{~K}$ & 66.65 & 58.83 & 125.4 & 23.71 & 883 & 124 & 2.47 & 1.98 \\
\hline
\end{tabular}

Source: Census of India, 2011, Directorate of Statistics and Economics, Govt. Jammu \& Kashmir, 2011-12

Note: In 2006 new eight (8) districts were created in the Azad-led government, Kishtwar, Samba, Reasi and Ramban new districts in the Jammu division and Bandipore, Kulgam, Ganderbal and Shopian in the Kashmir valley.

However, the population density of state varies highly among the districts. District Ganderbal (1151 per sq km) accounts highest proportion followed by and
Bandipora(1117) whereas district Leh and Kargil accounts only 3 and 10. 


\section{RETROSPECTIVE FEATURES OF JAMMU AND KASHMIR DEMOGRAPHIC}

Demographic transition is the important feature for understanding State's development that is, studying various aspects of development. It represents past achievements or trends and makes some firm statements about the future where the state is going. Furthermore, attempts to explain why the economies have more or less passed through the same three stages of population growth (Theory of Demographic Transition). Before the economic modernization, these economies had stable or very slow growing population combination of high birth rate and high death rate. With economic development resulting in higher incomes, improving health facilities, there was marked decline in mortality that gradually raised life expectancy. With declining death rate but birth rate not falling correspondingly, these economies passed through stage two, marking slow growing population to rapidly increasing number. Finally, stage third is reached when the influences of modernization and economic development cause fertility to decline so that eventually falling of birth rate converge with lower death rate leaving little or no population growth (Dyson, 1988) ${ }^{3}$.

The workforce of a state is closely controlled by a large number of demographic factors. The size of population, the birth rate, the death rate, the longevity, migration, literacy, education, general health of people, the occupation of the people, per capita income attitude towards life and standard of living influence the availability of workforce in a society (Roy, 2008) . $^{5}$

In this context we propose to discuss the following demographic trends in view of historical perspectives of J\&K State like sex composition of population, population density, literacy rate etc. The salient demographic characteristics of the Jammu and Kashmir State have been elaborated in the following paragraphs: -

\section{A. Sex Composition, 1981-2011}

The sex composition of a population helps in understanding the demographic processes of fertility, mortality and migration. The spatial pattern of sex ratio reveals a high degree of variation at district level. Kulgam and Shupian have highest sex ratio as per 2011 and 2001 census and replaced Samba and Udhampur. Kargil registered least sex ratio of 775 per thousand.

\section{B. District Wise Sex-Ratio, 1981-2011}

An important concern in the present status of Jammu and Kashmir's demographic transition relates to adverse sex ratio. Since 1981 nothing has happened to change the attitude of the people in respect of their preference for sons. The low sex ratio in the state may be attributed to the high mortality rate among the females on account of negligence of female children. Girls receive less medical attention than boys. Study further argues that there is mounting evidence of sex-selective abortion in some districts of the state (Report: Health \& Family Welfare, 2013-14) ${ }^{35}$. The district wise sex-ratio since 1981 is shown in the table.

TABle V District Wise SeX-Ratio of J \& K State, 1981-2011, Per 1000

\begin{tabular}{|l|c|c|c|c|}
\hline \multicolumn{1}{|c|}{ District } & $\mathbf{1 9 8 1}$ & $\mathbf{1 9 9 1}$ & $\mathbf{2 0 0 1}$ & $\mathbf{2 0 1 1}$ \\
\hline Kupwara & 858 & 882 & 906 & 843 \\
\hline Badgam & 880 & 906 & 931 & 88 \\
\hline Leh & 886 & 854 & 823 & 583 \\
\hline Kargil & 853 & 845 & 837 & 775 \\
\hline Punch & 889 & 904 & 919 & 890 \\
\hline Rajouri & 906 & 892 & 878 & 863 \\
\hline Kathua & 917 & 908 & 898 & 877 \\
\hline Baramulla & 876 & 891 & 905 & 873 \\
\hline Bandipora & 858 & 876 & 894 & 911 \\
\hline Srinagar & 873 & 857 & 841 & 879 \\
\hline Ganderbal & 871 & 894 & 917 & 869 \\
\hline Pulwama & 906 & 919 & 942 & 913 \\
\hline Shupiyan & 876 & 913 & 950 & 951 \\
\hline Anantnag & 888 & 900 & 911 & 937 \\
\hline Kulgam & 887 & 916 & 945 & 951 \\
\hline Doda & 904 & 909 & 913 & 922 \\
\hline Ramban & 867 & 878 & 889 & 901 \\
\hline Kishtwar & 896 & 900 & 904 & 917 \\
\hline Udhampur & 934 & 876 & 846 & 863 \\
\hline Reasi & 864 & 872 & 880 & 891 \\
\hline Jammu & 912 & 889 & 865 & 871 \\
\hline Samba & 945 & 896 & 897 & 886 \\
\hline J \& K & 892 & 892 & 892 & 883 \\
\hline India & 934 & 927 & 933 & 943 \\
\hline Compiled from Census of India
\end{tabular}

Source: Compiled from Census of India

Note: Data of newly Created districts in 2006 stands at Tehsil level in $1981 \& 2001$

The sex ratio in the State is adverse in the sense that in 1981 there were 892 female per 1000 males against 934 at national level. The sex-ratio as per census 2001 is 892 against 933 at national level. The sex-ratio as per census 2011 was 883 against 940 at national level which is a matter of great concern and needs to be addressed on priority. It is also depicts higher mortality rates for females in the state due to low level of social development.Furthermore, the Division of Kashmir has only 878 females per 1000 of males, while in Jammu and Ladakh Divisions, the sex ratio stands at 925 and 879 respectively. The Division of Kashmir having over 95 percent of Muslim population has a low sex ratio. In fact, many of the Muslim boys are not getting married and in many cases the bridegrooms have to pay a substantial amount to the parents of brides (Report: $H F W, 2008-09)^{34}$. 


\section{Age Structure or Age Composition, 1981-2011}

Age structure is an important characteristic of population which determines the workforce and dependency ratio. Now considering J\&K State, the dependency ratio is significantly high which reflects feature of developing societies. The age groups of State Population at national level since 1981 have been given in table.

TABLe VI Population Age GROUPS OF J\&K STATE, 1981-2011, (PERCENTAG)
\begin{tabular}{|c|c|c|c|c|c|c|}
\hline Jammu and Kashmir State & \multicolumn{3}{c|}{ All India } \\
\hline Age Group & $\mathbf{1 9 8 1}$ & $\mathbf{2 0 0 1}$ & $\mathbf{2 0 1 1}$ & $\mathbf{1 9 8 1}$ & $\mathbf{2 0 0 1}$ & $\mathbf{2 0 1 1}$ \\
\hline $0-4$ & 13.34 & 9.49 & 7.3 & 14.3 & 12.8 & 9.7 \\
\hline $5-14$ & 25.95 & 26.15 & 17.6 & 26.4 & 22.6 & 19.7 \\
\hline $15-59$ & 54.97 & 57.23 & 65.9 & 54.1 & 57.1 & 62.5 \\
\hline 60 \& Above & 5.67 & 7.13 & 8.4 & 6.2 & 7.5 & 8.0 \\
\hline
\end{tabular}

Source: - Census of India, 1981, 2001 \& 2011/ Statistical Report, Registrar General of India

According to census $1981^{13}$, age group 0-14 posses somewhat large proportion $(13.34 \%)$ then declined $9.49 \%$ (2001) and $7.7 \%$ (2011). Fortunately age group of 15-59 continuously maintains the dominance since 1981. According to census 2011, large proportion of population are trapped in the age group of 15-59 (65.9\%) followed by group 5-14 (26.15 percent). Thus the state's potential for creating job opportunities can meet the increasing demand for employment as a consequence of increasing proportion of adult population.
D. Birth Rate and Death Rate of Jammu \& Kashmir, 19701998

$\mathrm{J} \& \mathrm{~K}$ state has performed well in providing health and medical facilities to the people. The number of health institutions has increased substantially in the recent past. The health indicators have improved and indicate the following position over the last five decades as shown in table. The birth rate and death rate for the state from 1971 to 2011 is shown in the table below:-

TABLE VII BiRTh RATE, Death RATE AND IMR FOR J\&K STATE, (PER 1000)

\begin{tabular}{|c|l|c|l|c|l|c|}
\hline Years & \multicolumn{2}{|c|}{ Birth Rate } & \multicolumn{2}{c|}{ Death Rate } & Infant Motility Rate \\
\hline \multirow{4}{*}{1971} & Combined & 21.44 & Combined & 7.19 & Combined & 71 \\
\cline { 2 - 7 } & Rural & 22.19 & Rural & 11.7 & Rural & 84 \\
\cline { 2 - 7 } & Urban & 20.89 & Urban & 6.02 & Urban & 57 \\
\hline \multirow{4}{*}{1981} & Combined & 31.6 & Combined & 9.0 & Combined & 72 \\
\cline { 2 - 7 } & Rural & 33.9 & Rural & 9.7 & Rural & 81 \\
\cline { 2 - 7 } & Urban & 21.4 & Urban & 6.0 & Urban & 63 \\
\hline \multirow{4}{*}{2001} & Combined & 20.2 & Combined & 6.1 & Combined & 50 \\
\cline { 2 - 7 } & Rural & 21.1 & Rural & 6.1 & Rural & 51 \\
\cline { 2 - 7 } & Urban & 16.4 & Urban & 6.1 & Urban & 45 \\
\hline \multirow{3}{*}{2011} & Combined & 18.6 & Combined & 5.7 & Combined & 45 \\
\cline { 2 - 7 } & Rural & 19.9 & Rural & 6.0 & Rural & 48 \\
\cline { 2 - 6 } & Urban & 13.7 & Urban & 4.7 & Urban & 34 \\
\hline \multirow{3}{*}{ Source: Various Reports of Health and Family Welfare, GoI } & \\
\cline { 2 - 6 } & & & & \\
\end{tabular}

From the above estimates, it can be inferred that vital indicators BR, DR \& IMR have come down, reflect a satisfactory picture of health status of J\&K state. However, death rate is lower in urban areas which can be attributed to better health care and health standards in urban areas. Similarly, table shows the high birth rate in rural areas which can be attributed to illiteracy and less acceptance to family planning measures.

\section{BIRTH RATE (BR) AND DEATH RATE (DR) AT NATIONAL LEVEL}

The difference between birth rate (BR) and death rate (DR) gives the estimate of growth rate. The most encouraging and important fact is that both the birth and death rates in the state remained quite below than national average. The birth and death rate at both levels slumped during 1981 to 2011; however, nation experienced faster speed than state.

\section{A. Density of Population}

The density of population in the state has shown tremendous increase after independence. It has increased from 32 to 124 persons per $\mathrm{km}^{2}$ in 1951 to 2011 generally by the rapid rate of population. The density of population has increased more than two fold in the last 50 years only. Srinagar and Jammu districts recorded high density of population of 703 and 596 
persons per $\mathrm{km}^{2}$ respectively, mainly on account of being the state's administrative capitals which have made them the hub of socio-economic activities. .The lowest population density is found in the Leh district with only 3 persons per $\mathrm{km}^{2}$. The population density of since 1981 shown in table.

TABLE VIII BIRTH RATE AND DEATH RATE OF J \& K STATE, 1981 \& 2011

\begin{tabular}{|c|c|c|c|c|}
\hline & Birth rate/1000 Population & Death rate/1000 Population \\
\hline Year & J \& K & India & J \& K & India \\
\hline 1981 & 20.2 & 28.4 & 6.1 & 9.3 \\
\hline 2001 & 19.9 & 25.8 & 5.4 & 8.4 \\
\hline 2011 & 19.9 & 21.8 & 5.5 & 7.2 \\
\hline
\end{tabular}

TABLE IX POPULATION DENSITY OF J \& K STATE, 1981-2011

\begin{tabular}{|l|c|c|c|c|c|}
\hline \multirow{2}{*}{$\begin{array}{c}\text { State/ } \\
\text { Districts }\end{array}$} & Area sq. kms & \multicolumn{4}{|c|}{ Density (Persons per sq. km of area) } \\
\cline { 3 - 6 } & & $\mathbf{1 9 8 1}$ & $\mathbf{1 9 9 1}$ & $\mathbf{2 0 0 1}$ & $\mathbf{2 0 1 1}$ \\
\hline Anantnag & 3984 & 165 & 207 & 294 & 375 \\
\hline Pulwama & 1398 & 289 & 369 & 464 & 594 \\
\hline Srinagar & 2228 & 318 & 401 & 531 & 703 \\
\hline Badgam & 1371 & 268 & 263 & 461 & 537 \\
\hline Baramulla & 4588 & 146 & 188 & 252 & 305 \\
\hline Kupwara & 2379 & 138 & 175 & 269 & 368 \\
\hline Leh & 82665 & $2(\mathrm{a})$ & $2(\mathrm{a})$ & $3(\mathrm{a})$ & 3 \\
\hline Kargil & 14036 & 5 & 6 & 8 & 10 \\
\hline Jammu & 3097 & 305 & 390 & 508 & 596 \\
\hline Udampur & 4550 & 100 & 132 & 162 & 211 \\
\hline Doda & 11691 & 36 & 45 & 59 & 79 \\
\hline Kathua & 2651 & 139 & 186 & 205 & 232 \\
\hline Rajouri & 2630 & 115 & 159 & 182 & 235 \\
\hline Poonch & 1674 & 134 & 175 & 222 & 285 \\
\hline J \& K & $222236 \mathrm{SqKms}$ & $59(\mathrm{a})$ & $76(\mathrm{a})$ & $99(\mathrm{a})$ & 124 \\
\hline All India & $3287263 \mathrm{SqKms}$ & 240 & 298 & 324 & 382 \\
\hline
\end{tabular}

Including 78114 sq. kms under Pakistan, 5180 sq. kms handed over by Pakistan to China. Source: Census of India $1981 \& 2011, \mathrm{~J} \& \mathrm{~K}$

The service activities played significant role in population concentration in Srinagar, Badgam, Pulwama, Anantnag and Baramulla district. Similarly in Jammu division high concentration and high density of population is found in Jammu plains consisting of Jammu and Kathua districts. On the other hand, Leh, Kargil and Doda districts recorded least density of population due to harsh environment control and the absence of social and economic development activities.

Since 1981, Srinagar was the most thickly populated district followed by Jammu district. As per 2001 Census, Srinagar district has 531 souls per sq. km, while as Jammu has 508 souls per sq. $\mathrm{km}$. Leh has the lowest density of 3 souls per sq.km. Srinagar, Jammu, Pulwam and Badgam districts constitute the zone of highest density in the State. This is due to variety of factors such as level of land, fertile character of the soil, moderate climate and availability of adequate irrigational facilities besides higher level of economic development.Against the national density of 382 souls per sq. km., Jammu and Kashmir State stands at 124 in 2011 .

\section{B. Literacy Rate of Jammu And Kashmir, 1981-2011}

Literacy rate is a vital parameter to gauge the socioeconomic transformation of the population. The process of education in terms of improved qualification and skills would help in the formation of human capital stock which has an overwhelming influence on the socio-economic development of a region as it determines the rate and pattern of resource utilization. The district wise literacy rate, 1981 to 2001 is reflected in the table below:-

District wise literacy rate of State is examined since 1981. During 1981 only four districts, namely Srinagar $(33.90 \%)$, Jammu (42.86 \%), Kathua (31.90) and Leh (25.17\%), the literacy rate was over 25 percent, while in other three districts, namely Badgam (17.86\%), Kargil (18.86) and 
Doda (18.50) possess less than 20 percent of literacy rate. The literacy rate in the remaining districts varied between 20 to 25 percent. However, with the passage of time, the literacy rate increase steadily due to several schemes and backward and economically deprived areas were given special attention. It inceased almost two fold.

According to census 2011, literacy rate of J\&K stands 68.74 percent. District Jammu (83.98 percent) persistently maintains dominance since census 1981.

\section{Literacy Rate at National Level}

According to the census of 1981, literacy rate of the state stood only 26.67 percent against national average of 41.43 percent. During 1981 to 2011, the literacy rate increased by 42.07 against 31.57 percent at national level shown the table below.

As per census of 2011, the literacy rate of the state is 68.74 percent against 74.04 percent at national level. Male and female literacy rate accounts 78.26 percent and 58.01 percent against the national average of 82.14 percent and 65.46 percent. The district-wise pattern of literacy rate indicates high rate for Jammu, Samba and Leh district, while low literacy rates for Ramban, Bandipora and Badgam districts in the State. Female literacy rate is low in all districts. This reflects a poor social awareness for female education due to existing socio-cultural beliefs.
TABLE X DisTRICT WISE LITERACY RATE OF J \& K STATE, 1981

\begin{tabular}{|l|c|c|c|}
\hline \multicolumn{1}{|c|}{ Districts } & $\mathbf{1 9 8 1}$ & $\mathbf{2 0 0 1}$ & $\mathbf{2 0 1 1}$ \\
\hline Anantnag & 22.93 & 51.27 & 64.32 \\
\hline Pulwama & 20.47 & 54.62 & 65.00 \\
\hline Srinagar & 33.90 & 50.57 & 71.21 \\
\hline Budgam & 17.86 & 47.60 & 57.98 \\
\hline Baramulla & 20.62 & 51.12 & 66.93 \\
\hline Kupwara & 16.82 & 51.36 & 66.92 \\
\hline Leh & 25.17 & 68.84 & 80.48 \\
\hline Kargil & 18.86 & 68.35 & 74.49 \\
\hline Jammu & 42.86 & 77.87 & 83.98 \\
\hline Udhampur & 23.50 & 66.97 & 69.90 \\
\hline Doda & 18.50 & 63.74 & 65.97 \\
\hline Kathua & 31.90 & 71.68 & 73.50 \\
\hline Rajouri & 24.73 & 71.02 & 68.54 \\
\hline Poonch & 23.39 & 68.62 & 68.69 \\
\hline Jammu \& Kashmir State & 26.67 & 54.46 & 68.74 \\
\hline
\end{tabular}

Note: In 2006 new eight (8) districts were created in the Azad-led government, Kishtwar (58.54), Samba (82.48), Reasi (59.42) andRamban

(56.90) new districts in the Jammu division and Bandipore (57.82),

Kulgam (60.35), Ganderbal (59.99) and Shopian (62.49) in the Kashmir valley according to census 2011.

TABLE XI LITERACY RATE OF JAMMU AND KASHMIR AT ALL INDIA LEVEL

\begin{tabular}{|c|c|c|c|c|c|c|}
\hline \multicolumn{3}{|c|}{ Jammu and Kashmir State } & \multicolumn{3}{c|}{ All India } \\
\hline & Literacy Rate & Male & Female & Literacy Rate & Male & Female \\
\hline 1981 & 26.67 & 36.29 & 15.88 & 41.43 & 53.46 & 28.47 \\
\hline 2001 & 54.46 & 65.75 & 41.82 & 65.38 & 75.85 & 54.16 \\
\hline 2011 & 68.74 & 78.26 & 58.01 & 73.0 & 80.9 & 64.6 \\
\hline
\end{tabular}

\section{Religious Composition}

The religious composition has great social and economic relevance.
The religious composition for state of 1981 has been given in table.

TABLE XII RELIGIOUS COMPOSITION OF JAMMU AND KASHMIR STATE, 1981

\begin{tabular}{|c|c|c|c|c|c|}
\hline Division & Muslims & Hindus & Sikhs & Buddhists & Others \\
\hline Kashmir & 94.00 & 4.42 & 1.20 & 0.05 & 0.33 \\
\hline Jammu & 33.81 & 62.06 & 3.67 & 0.11 & 0.35 \\
\hline Ladakh & 44.66 & 0.01 & ---- & 51.82 & 3.51 \\
\hline Total & 65.84 & 30.41 & 1.06 & 1.26 & 0.19 \\
\hline
\end{tabular}

Source: - Victoria Schofield (2001) Kashmir in Crossfire, London, B Taurus Publishers

It is examined that nearly 66 percent of the total population of the J\&K state consists of Muslims and 30.41 percent of Hindus. Buddhists with 1.26 percent constitute the third largest religious group followed by Sikhs $(1.06 \%)$ in the state. There are however, significant spatial variations in the concentrating of different religious groups. In the Kashmir Division, Muslims have an overwhelming majority constituting 94 percent of population and in Jammu Division about 62 percent are Hindus, while in Ladakh Division 51.82 percent are Buddhists. Thus spatial variation in the population of different regions are quite significant. The Religious composition of J\&K State since 1981 is depicted in the table below. 
TABLE XIII RELIGIOUS COMPOSITION OF J\&K STATE, 1981- 2011

\begin{tabular}{|c|c|c|c|}
\hline & 1981 & 2001 & 2011 \\
\hline Muslim & 64.19 & 66.97 & 68.31 \\
\hline Hindusism & 32.24 & 29.63 & 28.44 \\
\hline Sikhism & 2.23 & 2.04 & 1.9 \\
\hline Buddhism & 1.16 & 1.12 & 0.9 \\
\hline Christainty & 0.19 & 0.20 & 0.30 \\
\hline Janism & 0.03 & 0.02 & 0.01 \\
\hline Others & 0.02 & 0.01 & 0.01 \\
\hline
\end{tabular}

Source: The First Report on Religion Data, New Delhi, 2004

Source: Victoria Schofield (2001) Kashmir in Crossfire, London, B Taurus Publishers

Source: Census of India, 2011

Expectedly, very large variations are found in the percentage of different religious communities since 1981. The State possesses large proportion of Muslims and India followed by Hindu proportion. As per the last 2011 census, Jammu and Kashmir is Muslim majority state in India with approximately 68.31 percent of population following Islam. Hinduism is the second popular religion in the State with approximately 28.44 percent following it. While 1.9 percent followed Sikhism and small proportion follow Buddhism (0.9 percent), Christianity (0.3 percent), Jainism (0.01) and other (0.01).

\section{Life Expectancy of Jammu and Kashmir}

Jammu and Kashmir has surpassed Kerala as the state with the highest life expectancy in India, according to the latest data released (on Oct. 19, 2016) by Registrar General of India custodian of census data. The report from Sample Registration Survey provides life expectancy at birth for year 2002-06 and 2010-14 for J\&K 72.6 and 74.6 against All India figure of 67.9 and 63.5. This hasn't happened overnight as it took more than three decades to reach to this level along with constant efforts from the state. While going to the retrospection, in $1970-75, \mathrm{~J} \& \mathrm{~K}$ had a total life expectancy of 56.1 years with 56.9 for men and 55.2 for women whereas Kerala in the same period of 1970-75 had a total life expectancy of 62.0 with 60.8 for men and 63.3 for women. J\&K State was behind Kerala, Punjab (57.9), and Haryana (57.5).

According to National Family Health Survey, 2016-17, J\&K stands at the rank two with 2,812 hospitals after Rajasthan. The J\&K has higher number of health institutions than neighboring Himachal Pradesh (160), Punjab (240), and Haryana (159). J\&K has a total of 637 Primary Health Centres, 84, Community Health Centres and 23 district hospitals.

\section{E. Occupational Structure}

Estimates with regard to sectoral structure reveal that in consistent with the declining contribution of primary sector towards GSDP, the labor absorption of this sector shows a $\mathrm{dwindling}$ trend. And the tertiary sector occupied this place as the employment generation and secondary sector has remained more or less constant over the period except for the decade 1971-81.

\begin{tabular}{|c|c|c|c|c|c|}
\hline Occupation & 1961 & 1971 & 1981 & 2001 & 2011 \\
\hline Primary Sector & 78.62 & 71.05 & 64.28 & 50.1 & 43.10 \\
\hline Secondary Sector & 9.03 & 8.94 & 14.27 & 6.2 & 8.4 \\
\hline Tertiary Sector & 12.35 & 20.01 & 21.45 & 43.7 & 48.5 \\
\hline
\end{tabular}

From the table above, it is interesting to note that from 1961 to 2011 , the sharp fall from 78.62 percent to 43.10 percent in primary sector took place which has been compensated by a sharp and unprecedented increase in the tertiary sector by 12.35 percent to 48.5 percent.

The number of cultivators shows the consistent decline from 1961-2011 and the direct labor absorption capacity of agriculture during the five decades of planning is reduced by one half. The agriculture can be attributed to sharp decline in the size of holdings during 60s as compared to $50 \mathrm{~s}$ and absence of industrialization during the said decade.

Jammu and Kashmir witnessed rapid rate of population. Work force increases with the increase of population, however, the pace of workforce is very low than population. The working population between the periods of 1981 to 2011 is shown in the table below.

TABLE XV WORKING POPULATION OF J \& K, 1981-2011 (LAKHS)

\begin{tabular}{|c|c|c|c|c|c|c|c|c|}
\hline Year & Pop & $\begin{array}{c}\text { Work } \\
\text { force }\end{array}$ & \%age & Male Workers & \%age & Female Workers & \%age & D. I \\
\hline 1981 & 59.87 & 26.50 & 47.85 & 17.66 & 66.64 & 8.83 & 33.35 & 0.601 \\
\hline 2001 & 100.69 & 29.51 & 29.30 & 26.41 & 89.79 & 3.10 & 10.21 & 0.881 \\
\hline 2011 & 125.48 & 43.22 & 34.44 & 30.95 & 71.61 & 12.27 & 28.38 & 0.805 \\
\hline
\end{tabular}

Source: Economic census, Govt. of India, various issues 


\begin{tabular}{|c|l|c|c|}
\hline \multicolumn{4}{|c|}{ Correlations } \\
\hline \multirow{4}{*}{ Year } & Pearson Correlation & 1 & $.917^{*}$ \\
\cline { 2 - 4 } & Sig. (2-tailed) & & .028 \\
\cline { 2 - 4 } & $\mathrm{N}$ & 5 & 5 \\
\hline \multirow{4}{*}{ Total workers } & Pearson Correlation & $.917^{*}$ & 1 \\
\cline { 2 - 4 } & Sig. (2-tailed) & .028 & \\
\cline { 2 - 4 } & $\mathrm{N}$ & 5 & 5 \\
\hline \multicolumn{3}{|c|}{ *. Correlation is significant at the 0.05 level (2-tailed). } \\
\hline \multirow{3}{*}{ D.I. = $\log (\mathrm{X} 1 / \mathrm{X} 2)+\log$ (100-X2/100-X1), M=male, F = female }
\end{tabular}

The analysis of workforce during 1981 period, the State accounts 26.50 lakh of work force that stood 47.85 percent from total population. Male accounts 17.66 lakh (66.64\%) and female accounts 8.83 lakh (33.35\%). During 2001, the total workforce accounts 29.51 lakh, stood 29.31 percent from total population. Male accounts 26.41 lakh (71.60\%) and female accounts 10.47 lakh (28.39\%). In 2011, the same stood 43.22 lakh $(34.44 \%)$ with male 71.60 percent and female 12.27 percent. During the three decade period 1981 to 2011, workers-population ratio is low due to rapid growth of population, low female participation in labour and underenumeration and omission of unpaid family workers even when according to the accepted concept they are to be classified as workers.

\section{F. Urbanization}

Urbanization is a part of development process. Its process is fast in rapidly growing economies where newly established industries and ancillary activities continuously provide jobs to people who wish to migrate to cities (Dyson, 1988) ${ }^{2}$.

The development experience of various economies reveals that the growth process and structural transformations move concurrently. The decline in the contribution of agriculture and growth in the contribution of manufacturing and tertiary sector give fillip to process of urbanization.

TABLE XVI URBAN POPULATION AND DENSITY OF POPULATION FOR J\&K STATE

\begin{tabular}{|c|c|c|c|c|}
\hline Year & Urban Population (J\&K) & Kashmir Division & Jammu Division & Density \\
\hline 1961 & 16.66 & 20.21 & 12.18 & NA \\
\hline 1971 & 18.59 & 23.14 & 13.81 & 45 \\
\hline 1981 & 21.05 & 25.20 & 14.61 & 59 \\
\hline 2001 & 24.81 & 26.52 & 22.62 & 100 \\
\hline 2011 & 27.21 & 31.70 & 31.02 & 124 \\
\hline
\end{tabular}

While analyzing urban population since 1961 in terms of percentage, it has steadily increased from 16.66 percent to 27.21 percent up to 2011. At the provincial level though similar pattern is observable yet some interesting aspects call for special attention. In Kashmir division, the process of urbanization has increased from 20.21 percent to 31.70 from 1961 to 2011 respectively. While as in the Jammu division correspondingly estimates are 12.18 percent and 22.02 percent. Interestingly Jammu division experiences the highest increase in proportion of urban population particularly during 1981 to 2001 because of migration from Kashmir due to turmoil.

The state of Jammu and Kashmir has almost 27.21 percent in 2011 of the total population in urban areas. In the case of Kashmir division, major urban centers are concentrated mainly along Jhelum Valley Floor recording 95 per cent of the total urban population of Kashmir division. The other regions have negligible proportion of urban population. The
Srinagar urban agglomeration recorded a concentration of 35.52 percent of the state urban population, whereas the Jammu city, the second largest urban centre in the state, registered 22.28 percent of urban population. Thus, the two cities together constitute 57.80 percent of the total urban population. It indicates that these two cities occupy primate city position having concentration of economic and service activities. The district wise proportion of urban population indicates huge disparity.

\section{CONCLUSION}

To sum up, demographic characteristics provide an overview of population size, composition and territorial distribution of population, density and dependency ratio, birth rate, death rate, and natural growth rate and migration and occupational pattern. These indicators for the state will help in identifying areas that need policy and programmed interventions, setting near and far-term goals, and deciding 
priorities, besides understanding them in an integrated structure.

\section{REFERENCES}

[1] Kalhana (1148 A.D), "Rajtarangani”- A History of Kashmir

[2] Tim Dyson (1988), "The Cause of Demographic Change", Experiment Research in South India, Madison: University of Wisconsin Press

[3] Tim Dyson (1988), “India's Demographic Transition and its Consequences for Development”, Indian Economy Edited by Uma Kapila, 40 ${ }^{\text {th }}$ Edition 2013-14, Academic Foundation, New Delhi

[4] Victoria Schofield (2001), "Kashmir in Crossfire”, London: B Taurus Publishers

[5] Satyaki Roy (2008), "Structural Change in Employment in India Since 1980s", ISID VasantKunj, New Delh

[6] Darpun P. (2016-17), "Indian Economy"

[7] Rahman M. (1996), "Divided Kashmir: Old Problems, New Opportunities for India, Pakistan, and the Kashmiri People”, Boulder: Lynne Rienner

[8] ShahidBurki (2007), "Kashmir: A Problem in Search of a Solution”, Washington, DC: United States Institute of Peace, 2007, p. 15.

[9] Census of India 1921, Jammu and Kashmir, Part I, Vol. XXII, Lahore, 1923, pp. 161-2.

[10] Census of India 1941, Jammu and Kashmir, Parts I and II, Vol. XXII, Jammu, 1943, p. 7.

[11] Land Committee Report, J\&K Govt., 1951-52

[12] Census of India 1971, Vol. I, India Part II A, Union Primary Census Abstract.

[13] Census of India, 1981 (Series 8, Jammu \& Kashmir), Registrar General of India

[14] Census of India 2001, Series 2, Jammu \& Kashmir Provisional Population Totals, Paper -1 .

[15] Census of India 2011, Jammu \& Kashmir, Series -02, Part XII-B, Primary Census Abstract.

[16] $2^{\text {th }}$ Economic Census (1980), Ministry of Planning \&Programme Implementation (Department of Statistics), Central Statistical Organization, New Delhi.

[17] $3^{\text {th }}$ Economic Census (1990), MOPPI, (Department of Statistics), CSO, New Delhi.

[18] $4^{\text {th }}$ Economic Census (1998), Ministry of Statistics \&Programme Implementation (Department of Statistics), Central Statistical Organization, New Delhi.
[19] $5^{\text {th }}$ Economic Census (2005), MOSPI (Department of Statistics), CSO, New Delhi.

[20] $6^{\text {th }}$ Economic Census (2013), MOSPI (Department of Statistics), CSO, New Delhi.

[21] NSS 32 ${ }^{\text {nd }}$ Round (1972), National Sample Survey, Conducted by NNS Organisation. However, in 1972, NSS replaced to NSSO under Ministry of Planning \&Programme Implementation (Department of Statistics), Central Statistical Organization, New Delhi.

[22] NSSO 50 ${ }^{\text {th }}$ Round (July 1993- June 1994), Employment \& Unemployment Survey, Ministry of Statistics \&Programme Implementation (MOSPI), Department of Statistics, Central Statistical Organization, New Delhi.

[23] NSSO 54 ${ }^{\text {th }}$ Round (January 1998- June 1998), Employment \& Unemployment Survey, MOSPI (Department of Statistics), CSO, New Delhi.

[24] Statistical Abstract of India, 1999, MOSPI, CSO, New Delhi, New Delhi.

[25] NSSO 68 $8^{\text {th }}$ Round (July 2011- June 2012), Domestic Tourism, MOSPI (Department of Statistics), New Delhi.

[26] NSSO $71^{\text {st }}$ Round ((January-June 2014), Social Consumption: Education, MOSPI (Dept of Statistics), New Delhi.

[27] Directorate of Economics and Statistics, Government of $\mathbf{J} \& \mathrm{~K}$, 1980-81

[28] Directorate of Economics and Statistics, Government of J \& K, 1995-96

[29] Directorate of Economic and statistics, Government of J\&K, 2001-01

[30] Directorate of Economics and Statistics, Government of $\mathrm{J} \& \mathrm{~K}$ 2006-07

[31] Directorate of Statistics and Economics, Govt. Jammu \& Kashmir 2011-12.

[32] Annual Report 1997-1998, Ministry of Health and Family Welfare, Government of India

[33] Annual Report 1999-2000, Ministry of Health and Family Welfare, Government of India

[34] Annual Report 2008-2009, Ministry of Health and Family Welfare, Government of India

[35] Annual Report 2013-2014, Ministry of Health and Family Welfare, Government of India

[36] JK Economic Survey, Directorate of Statistics and Economics, Government Jammu \& Kashmir 2013-14.

[37] JK Economic Survey, Directorate of Statistics and Economics, Government of Jammu \& Kashmir, 2016-17. 